\title{
Family Intervention: A Systematic Learning Approach for Children with Disabilities During Pandemic Covid-
}

\author{
19 \\ Muchamad Irvan ${ }^{1, *}$, Muhammad Nurrohman Jauhari ${ }^{2}$ \\ ${ }^{1}$ Department of Special Education, Faculty of Education, Universitas Negeri Malang, Malang, Indonesia \\ ${ }^{2}$ University of PGRI Adi Buana Surabaya, Indonesia \\ ${ }^{*}$ Corresponding author. Email: muchamad.irvan.fip@um.ac.id
}

\begin{abstract}
Currently, new problems arise in the learning scope for children with disabilities. During the pandemic covid-19, everyone is required to stay at home, including learning activities that must be done without coming to school. However, there are complaints from parents about the implementation of online learning. This article aims to examine the problems of implementing interventions that arise and consider the best solutions for various intervention problems that arise during pandemics. This study was situated in descriptive-qualitative methodology using a collective case study approach. This article examines the common problems that occur in the implementation of interventions against children with disabilities during pandemics. Based on the results of the above, the study can be concluded that the problem of intervention in children with disabilities in Indonesia during the outbreak is because the involvement of all experts is not well-formed. To minimize the problems, it is necessary that every member of the role actively briefs the family. Such efforts as a form of family intervention to implement the intervention program that must be implemented.
\end{abstract}

Keywords: family intervention, learning approach, children with special needs

\section{INTRODUCTION}

Some studies have proven the effectiveness of intensive interventions against children with disabilities. Learning for children with disabilities generally requires a strict referral procedure (Irvan and Dewi, 2018). Carrying out learning for children with disabilities needs to be done from an early age. This is important to minimize any problems that may arise in the future due to the child's condition (Irvan and Jauhari, 2019). Providing intervention to children with disabilities from an early age is also necessary to build children's learning readiness at the next level. Its intervention procedures require the cooperation of various parties to obtain significant results (Crossman et al., 2018; Reichrath, Witte, and Winkens, 2010). Various practitioners have a role in providing intervention programs. However, the role of a family at home also affects the significance of success (Tomasello, Manning, and Dulmus, 2010).

More than 30 years of practitioners have involved the role of parents in providing care to people with abuse problems. Providing interventions to families can build an integrative approach to identifying psychiatric problems individually (Hoffman et al., 1999). Through this approach can help them in putting together a program that fits their characteristics. In practice, experts provide special training for families according to individually required programs (Murawski and Hughes, 2009). The provision of collaborative actions has a huge impact on their development (Vanegas, Abdelrahim, and Abdelrahim, 2016).

Many cases in schizophrenic patients are cured through good collaboration between practitioners and families (Barrowclough et al., 2001). Practitioners conduct empirical evaluations of the family's performance in providing care at home. Furthermore, they developed continuously the advanced handling models that families need to be implemented easily and appropriately. Family intervention in other cases has also proven successfully where the family's skills in providing care to bipolar patients that have been trained (Grossman and Magaña 2017). For 9 months the practitioner provides special assistance to the family to understand and implement the training program that needs to be done intensively at home. The goal is to maintain a good collaboration in a relationship so that the development can be achieved quickly in various aspects 
of the child's ability. Currently, new problems arise in the learning scope for children with disabilities. During the pandemic covid-19, everyone is required to stay at home, including learning activities that must be done without coming to school.

Learning that generally takes place during the pandemic covid-19 period is through online (Verawardina et al., 2020; Aliyyah et al., 2020; Jauhari, Mambela, and Zakiah, 2020). The approach also applies to children with disabilities. The application of interventions made virtually through the most relevant video conference. However, there are complaints from parents about the implementation of online learning. This article aims to examine the problems of implementing interventions that arise and consider the best solutions for various intervention problems that arise during pandemics (Lindsay and Edwards 2013).

\section{METHODS}

This study was situated in descriptive-qualitative methodology using a collective case study approach (Denzin and Lincoln 2011). This article examines the common problems (Kim, Sefcik, and Bradway, 2017) that occur in the implementation of interventions against children with disabilities during pandemics. Researchers analyzed 100 parents who had randomly selected schoolage children in several regions of Indonesia.

This aims to find out the learning problems that are common during pandemics. Researchers also analyzed intervention performance during the pandemic on 100 parents who had children with disabilities. Both data were used as a fundamental comparison to determine specific problems with the implementation of interventions. Data collection was done using an open questionnaire where respondents could convey various information about the questions. The results of this data analysis were used as a basis in determining the procedures that should be performed between various parties in implementing interventions in children with disabilities.

\section{RESULTS}

The first step was collecting data on problems that occurred in the learning process during the pandemic. Based on the data collected, it showed only $20 \%$ of families that stated learning could run smoothly without constraints. Most families complained of problems in online learning for their child. The first factor (B) was difficulty dividing time between working and accompanying children to study. The second factor (C) was, the condition of income was below average while the staff did not correspond to the number of children, so they had to take turns using gadgets. The third factor (D) was an unstable network that forced children to look for signals outside the home. The fourth factor (E) was, the provision of improper tasks, so parents had to spend a full day accompanying the children to the task.

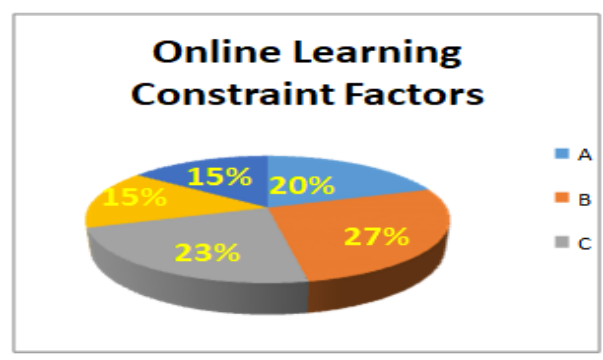

Figure 1 Online Learning Constraint Factors

Furthermore, the researcher gathered information about the implementation of interventions in children with disabilities during the pandemic. The interventions in question were not limited to one particular field but covered a wide range of medical, psychological, or pedagogical fields. The problems that occurred in the treatment of children with disabilities did not have a significant difference when it compared to learning in general.

Based on the results of the data collection, it showed that there were differences in the reason for the problem of intervention during the pandemic (Table 1). First, parents found it difficult to implement intervention programs. Second, children with disabilities were more difficult to adjust during online interventions. Therapists and teachers tried to solve learning problems as best they could and tried to ensure everything went well in times of pandemic. A common solution for teachers and therapists was to mentor parents. As a result, they tried to make regular home visits to provide services for families experiencing network problems or support facilities.

Furthermore, parents tried to implement programs that have been instructed by experts. Nevertheless, $28 \%$ of respondents feel that children are more difficult to control when they are at home. Approximately, $22 \%$ have difficulty practicing proper handling procedures because they are not used to doing. The next reason is another factor that includes the inadequate availability of learning media, the difficulty of dividing time, bad networks, and not having gadgets.

\section{DISCUSSION}

The COVID-19 virus has infected all countries around the world since the last few months (Tosepu et al. 2020). All sectors that concern the lives of many people are affected (Shereen et al. 2020). During the pandemic, all activities should be carried out at home. These conditions also apply to learn activities (Dewi 2020). However, not all schools in Indonesia can carry out learning activities online. Online learning in Indonesia becomes a polemic and family restless (Adnan and Anwar, 2020). 
Table 1 Percentage of Intervention Constraints during Pandemic

\begin{tabular}{|l|c|c|}
\hline Factors & Constrained & Streamlined \\
\hline Number of respondents & 77 & 23 \\
\hline $\begin{array}{l}\text { Difficult to implement an } \\
\text { intervention program }\end{array}$ & $22 \%$ & - \\
\hline Children are difficult to condition & $28 \%$ & - \\
\hline No adequate media & $9 \%$ & - \\
\hline Difficult to divide the time & $19 \%$ & - \\
\hline Bad network & $14 \%$ & - \\
\hline No gadget & $8 \%$ & - \\
\hline Percentage & $77 \%$ & $23 \%$ \\
\hline
\end{tabular}

There are several underlying factors: (1) difficulty dividing time between working and accompanying children to study; (2) lack of facilities due to belowaverage economic conditions; (3) or unstable internet access throughout the region; and (4) inappropriate learning programs (Djalante et al., 2020). Learning constraints are also commonly experienced in the implementation of interventions against children with disabilities. But specific reasons are underlying the problem of planning for children with disabilities becoming increasingly complex.

Children with disabilities are more difficult to condition to learn with gadgets ( $\mathrm{Liu}, \mathrm{Wu}$, and Chen, 2013). The condition is more widely complained by parents of children with ASD (autism spectrum disorder), ADHD (attention deficit hyperactive disorder), mental retardation, or other behavioral and social disorders. Next, parents are less able to train their children independently through the implementation of preplanned programs. This problem is more demonstrated in treatments that require care and patience such as the example of establishing joint attention in children with ASD, reducing easily dispersed behavior in children with ADHD, and so on.

Based on the results of the data analysis, it shows that there is a specific difference between the implementation of online learning in public schools and learning for children with disabilities in terms of the implementation program. Some things that can be assumed as the triggers are: (1) referral procedures are not performed properly; (2) the roles of various experts are not performed properly; (3) communication between parents and experts is not well established; (4) disadvantaged parents play an active role in the implementation of interventions.

The condition of the problem can have an adverse impact if it is not immediately determined solution efforts to fix it. Providing care to children with disabilities needs to be implemented on an ongoing basis to get progress (Armstrong et al. 2017). Some teachers try to do home visits to build good communication with parents (Villavicencio and López-larrosa, 2020). Teachers play an active role in motivating parents and delivering treatment programs that must be done at home. This step is done to minimize the constraints that occur during an online intervention (Murawski and Hughes, 2009).
The implementation of intervention programs in children with disabilities requires collaboration among some parties. Doctors, psychologists, therapists, teachers, and parents have their role in implementing treatment programs (Liaw, Young, and Farish, 1996; Kozub, McKay, and Columna, 2020). Parents have a relatively long time living with children at home, thus they have a greater role to play in the child's developmental progress (Strogilos and Stefanidis, 2015). Therefore: parents need to build good relationships and communication with related parties. Doctors, psychologists, therapists, and teachers have approaches that are matched by the characteristics and needs of the child. During interactive relationships, they are instrumental in implementing programs according to their field and should be able to guide parents to show what to do at home (Dickinson et al., 2020; Fassier et al., 2019). Furthermore, parents need to communicate the programs recommended by experts with each other. This is important so that every expert can modify and align the program.

Continuous handling involving the role of multiple experts is an important referral procedure for every parent to consider (Shirazipour et al., 2020). In this case, parents have a great influence on the development of the child. The relatively short duration (Rupp and Scott, 1998; Krause et al., 2001) of the meeting with experts cannot guarantee successful handling. Therefore, experts should be able to provide full support to the family. Experts are tasked with implementing intervention programs within their scope. However, the follow-up must be done in guiding the family relates to the actions that they must take at home. This can be referred to as family intervention. Family interventions have been implemented many years ago in various developed countries in providing the treatment of children with disabilities (Pelchat and Lefebvre, 2004). This approach proved to be a significant result when compared to interventions implemented only by some parties.

During the pandemic, experts were unable to implement intervention programs directly in children with disabilities. The condition triggers new problems in the context of learning (Pragholapati, 2020). The solutive effort that needs to be made is to use a family intervention approach (Vanderkerken et al., 2020). Family intervention emphasizes the active role of families in providing care for children with disabilities (Vanderkerken et al., 2020).

Intervention programs implemented wherever possible are modified to be more similar to daily activities. This strategy aims to make it easier for families to implement the program. Thus, the implementation of interventions is not only emphasized in parents only. Parents who have to share tasks with work can share roles with other family members. Experts are instrumental in monitoring the progress of the program's implementation periodically and evaluating (Genik et al., 2020) the 
child's development. Experts must also build communicative relationships to provide solutions to the various obstacles faced during the intervention implementation process.

\section{CONCLUSION}

The outbreak that plagued all corners of the region implemented interventions constrained. The direct contact of experts in children with disabilities should be stopped because activities must be carried out at home. The condition is widely complained by parents because several factors trigger the implementation of treatment online becoming constrained. The effort made does not bring much significant development in the child.

Based on the results of the above, the study can be concluded that the problem of intervention in children with disabilities in Indonesia during the outbreak is because the involvement of all experts is not wellformed. To minimize the problems, it is necessary that every member of the role actively briefs the family. Such efforts as a form of family intervention to implement the intervention program that must be implemented.

\section{REFERENCES}

[1] Adnan, Muhammad, and Kainat Anwar. 2020. "Online Learning amid the COVID-19 Pandemic: Students' Perspectives." Online Submission 2(1):45-51.

[2] Aliyyah, Rusi Rusmiati, Reza Rachmadtullah, Achmad Samsudin, Ernawulan Syaodih, Muhammad Nurtanto, and Anna Riana Suryanti Tambunan. 2020. "The Perceptions of Primary School Teachers of Online Learning during the COVID-19 Pandemic Period: A Case Study in Indonesia." Journal of Ethnic and Cultural Studies 7(2):90-109.

[3] Armstrong, Megan, D. Ph, Christopher Morris, D. Phil, Charles Abraham, D. Ph, Mark Tarrant, and D. Ph. 2017. "Interventions Utilising Contact with People with Disabilities to Improve Children 's Attitudes towards Disability: A Systematic Review And.” Disability and Health Journal 10(1):11-22.

[4] Crossman, Morgan K., Susan L. Parish, Penny Hausercram, Dolores Acevedo, and Marji Erickson. 2018. "Research in Developmental Disabilities The in Fl Uence of Early Intervention, Informal Support and the Family Environment on Trajectories of Competence for Fathers Raising Children with Developmental Disabilities." (November 2017).

[5] Denzin, Norman K., and Yvonna S. Lincoln. 2011. The Sage Handbook of Qualitative Research. Sage.

[6] Dewi, Wahyu Aji Fatma. 2020. "Dampak Covid-19 Terhadap Implementasi Pembelajaran Daring Di Sekolah Dasar.” Edukatif: Jurnal Ilmu Pendidikan 2(1):55-61.

[7] Dickinson, Corrine, Koa Whittingham, Jeanie Sheffield, Jane Wotherspoon, and Roslyn N. Boyd. 2020. "Efficacy of Interventions to Improve Psychological Adjustment for Parents of Infants with or at Risk of Neurodevelopmental Disability: A Systematic Review." Infant Mental Health Journal.

[8] Djalante, Riyanti, Jonatan Lassa, Davin Setiamarga, Choirul Mahfud, Aruminingsih Sudjatma, Mochamad Indrawan, Budi Haryanto, Muhammad Sabaruddin
Sinapoy, Irina Rafliana, and Susanti Djalante. 2020. "Review and Analysis of Current Responses to COVID19 in Indonesia: Period of January to March 2020." Progress in Disaster Science 100091.

[9] Fassier, Jean-Baptiste, Philippe Sarnin, Sabrina Rouat, Julien Peron, Gerjo Kok, Laurent Letrilliart, and Marion Lamort-Bouche. 2019. "Interventions Developed with the Intervention Mapping Protocol in Work Disability Prevention: A Systematic Review of the Literature.' Journal of Occupational Rehabilitation 29(1):11-24.

[10] Genik, Lara M., C. Meghan McMurtry, Paula C. Barata, Chantel C. Barney, and Stephen P. Lewis. 2020. "Study Protocol for a Multi-centre Parallel Two-group Randomized Controlled Trial Evaluating the Effectiveness and Impact of a Pain Assessment and Management Program for Respite Workers Supporting Children with Disabilities." Paediatric and Neonatal Pain 2(1):7-13.

[11] Grossman, Brian R., and Sandy Magaña. 2017. "Introduction to the Special Issue: Family Support of Persons with Disabilities Across the Life Course." Journal of Family Social Work 19(4):237-51.

[12] Irvan, Muchamad, and Dian Puspa Dewi. 2018. "Kajian Penanganan Terhadap Anak Berkebutuhan Khusus." Jurnal Abadimas Adi Buana 2(1):11-19.

[13] Irvan, Muchamad, and Muhammad Nurrohman Jauhari. 2019. "Early Intervention For Children With Autism Spectrum Disorder Using Planning Matrix." in The 9th International Conference on Educational Technology of Adi Buana (ICETA 9).

[14] Jauhari, Muhammad Nurrohman, Sambira Mambela, and Zykra Zakiah. 2020. "Dampak Pandemi Covid-19 Terhapad Pelaksanaan Pembelajaran Penjas Adaptif Di Sekolah Luar Biasa." STAND: Journal Sports Teaching and Development 1(1):63-70.

[16] Kim, Hyejin, Justine S. Sefcik, and Christine Bradway. 2017. "Characteristics of Qualitative Descriptive Studies: A Systematic Review." Research in Nursing and Health 40(1):23-42.

[17] Kozub, Francis M., Cathy McKay, and Luis Columna. 2020. "Research from the Perspectives of Teachers, Peers, and Parents." Routledge Handbook of Adapted Physical Education 410.

[18] Krause, Niklas, John W. Frank, Lisa K. Dasinger, Terry J. Sullivan, and Sandra J. Sinclair. 2001. "Determinants of Duration of Disability and Return-to-work after Workrelated Injury and Illness: Challenges for Future Research." American Journal of Industrial Medicine 40(4):464-84.

[19] Liaw, S. T., D. Young, and S. Farish. 1996. "Improving Patient-Doctor Concordance: An Intervention Study in General Practice." Family Practice 13(5):427-31.

[20] Lindsay, Sally, and Ashley Edwards. 2013. "Systematic Review of Disability Awareness Interventions for Children and Youth." 35(June 2012):623-46.

[21] Liu, Gi-zen, No-wei Wu, and Yi-wen Chen. 2013 "Research in Developmental Disabilities Review Article Identifying Emerging Trends for Implementing Learning Technology in Special Education: A State-of-the-Art Review of Selected Articles Published in 2008 - 2012.' Research in Developmental Disabilities 34(10):3618-28.

[22] Murawski, Wendy W., and Claire E. Hughes. 2009. "Response to Intervention, Collaboration, and $\mathrm{Co}$ Teaching: A Logical Combination for Successful Systemic Change." Preventing School Failure: Alternative Education for Children and Youth 53(4):26777. 
[23] Pelchat, Diane, and Helene Lefebvre. 2004. "A Holistic Intervention Programme for Families with a Child with a Disability." Journal of Advanced Nursing 48(2):124-31.

[24] Reichrath, Enid, Luc P. De Witte, and Ieke Winkens. 2010. "Interventions in General Education for Students with Disabilities :" 14(6):563-80.

[25] Rupp, Kalman, and Charles G. Scott. 1998. "Determinants of Duration on the Disability Rolls and Program Trends." Growth in Disability Benefits: Explanations and Policy Implications 139-76.

[26] Shereen, Muhammad Adnan, Suliman Khan, Abeer Kazmi, Nadia Bashir, and Rabeea Siddique. 2020. "COVID-19 Infection: Origin, Transmission, and Characteristics of Human Coronaviruses." Journal of Advanced Research 24:91-98.

[27] Shirazipour, Celina H., M. Blair Evans, Jennifer Leo, Alexander Lithopoulos, Kathleen A. Martin Ginis, and Amy E. Latimer-Cheung. 2020. "Program Conditions That Foster Quality Physical Activity Participation Experiences for People with a Physical Disability: A Systematic Review." Disability and Rehabilitation 42(2):147-55.

[28] Strogilos, Vasilis, and Abraham Stefanidis. 2015. "Contextual Antecedents of Co-Teaching Ef Fi Cacy: Their in Fl Uence on Students with Disabilities ' Learning Progress , Social Participation and Behaviour Improvement." Teaching and Teacher Education 47:21829.

[29] Tomasello, Nicole M., A. M. Y. R. Manning, and Catherine N. Dulmus. 2010. "Family-Centered Early Intervention for Infants and Toddlers With Disabilities." 163-72.
[30] Tosepu, Ramadhan, Joko Gunawan, Devi Savitri Effendy, Hariati Lestari, Hartati Bahar, and Pitrah Asfian. 2020. "Correlation between Weather and Covid-19 Pandemic in Jakarta, Indonesia." Science of The Total Environment 138436.

[31] Vanderkerken, Lien, Mieke Heyvaert, Patrick Onghena, and Bea Maes. 2020. "Family-Centered Practices in Home-Based Support for Families with Children with an Intellectual Disability: Judgments of Parents and Professionals." Journal of Intellectual Disabilities 1744629519897747

[32] Vanegas, Sandra B., Randa Abdelrahim, and Randa Abdelrahim. 2016. "Characterizing the Systems of Support for Families of Children with Disabilities: A Review of the Literature Children with Disabilities: A Review of the Literature." Journal of Family Social Work 00(00):1-42.

[33] Verawardina, Unung, Lise Asnur, Arina Luthfini Lubis, Yeka Hendriyani, Dochi Ramadhani, Ika Parma Dewi, Resmi Darni, Tigus Juni Betri, Wilda Susanti, and Titi Sriwahyuni. 2020. "Reviewing Online Learning Facing the Covid-19 Outbreak." Talent Development \& Excellence 12.

[34] Villavicencio, Carmita E., and Silvia López-larrosa. 2020. "Research in Developmental Disabilities Ecuadorian Mothers of Preschool Children with and without Intellectual Disabilities: Individual and Family Dimensions." Research in Developmental Disabilities 105(June): 103735

[35] Gunawan, I. (2013). Qualitative research methods. Jakarta: Bumi Aksara. 